\title{
COMPARISON OF LONG TERM TROPOSPHERIC OZONE TRENDS MEASURED BY LIDAR AND ECC OZONESONDES FROM 1991 TO 2010 IN SOUTHERN FRANCE
}

\author{
G. Ancellet ${ }^{1 *}$, A. Gaudel ${ }^{1}$, S. Godin-Beekmann ${ }^{1}$ \\ ${ }^{1}$ LATMOS, UPMC/CNRS/UVSQ, Paris, France *Email: gerard.ancellet@latmos.ipsl.fr
}

\begin{abstract}
ECC (Electrochemical Concentration Cell) ozonesondes and UV DIAL (DIfferential Absorption Lidar) measurements have been carried out simultaneously at OHP (Observatoire de Haute Provence, $44^{\circ} \mathrm{N}, 6.7^{\circ} \mathrm{E}, 690 \mathrm{~m}$ ) since 1991. A unique long-term trend assessment by two different instruments operated routinely at the same location is possible. Air mass trajectories have been calculated for all the ozone observations available at OHP. The bias between the seasonal mean calculated with lidar and ECC ozone vertical profiles for 4 timeperiods of 5 years is $0.6 \mathrm{ppbv}$ in the free troposphere $(4-8 \mathrm{~km})$. Larger differences $(>10$ ppbv) are explained by the need for clear sky conditions during lidar observations. The measurements of both instruments have been combined to decrease the impact of short-term atmospheric variability on the trend estimate.
\end{abstract}

\section{INTRODUCTION}

Considering the spatial and temporal variations of the tropospheric ozone trend calculated in Northern and central Europe [1], analysis of ozone vertical profiles in Southern Europe is missing. Regular lidar and ECC (Electrochemical Concentration Cell) ozonesondes are available since 1991 and can be used for a long-term trend analysis at OHP (Observatoire de Haute Provence, $44^{\circ} \mathrm{N}, 6.7^{\circ} \mathrm{E}$, $690 \mathrm{~m})$ ). A comparison of ozone inter-annual variability for these two instruments has not been made previously using such long time series. Furthermore, OHP is a good station to characterize the Mediterranean basin where there is a significant spatial positive anomaly of tropospheric ozone, especially during summer. In this contribution the tropospheric ozone data sets are described including a description of the transport patterns influencing OHP for both ECC and lidar data in section 1. Results of the comparison in terms of ozone inter-annual variability are then given in section 3 .

\section{METHODOLOGY}

Electrochemical ozonesondes have been launched every week since 1991 to measure the ozone vertical profile at OHP using Science Pump Corporation (SPC) for the period 01/1991-03/1997 and ENSCI (Z type) thereafter. Changing ozonesonde manufacturers may have introduced an ozone overestimate of $3 \%$ according to the BESOS 2004 campaign [2]. Therefore, from March 1997, we have applied a correction of $31 \%$ to the ENSCI data. The time evolution of the sonde normalization factor the DOBSON total ozone measurements at OHP shows a general decrease of the order of $5 \backslash \%$ during the 20-year period which may correspond to the use of the ENSCI sondes after 03/1997 The precision of ECC measurement was estimated to be in the range of $5-10 \backslash \%$ which corresponds to accuracy better than 5 ppbv [3].

Ozone is also measured between 3 and $14 \mathrm{~km}$ with the UV DIAL (DIfferential Absorption Lidar) technique using two wavelengths: 289$299 \mathrm{~nm}$ from 1990 to 1993 and 289-316 nm from 1993 until now [4]. The latter wavelength pair is generated with a single Raman cell filled with Deuterium and pumped with the 4th harmonic of a Nd-YAG laser. Data are usually recorded during at least one hour just after sunset. The ozone absorption cross sections are taken from Bass and Paur [5]. According to several studies, the uncertainty on the absorption cross section is within $1.5 \backslash \%$ near $290 \mathrm{~nm}$ [6]. The upper bound of the lidar measurement range corresponds to a statistical error less than $20 \backslash \%$. In this work, we do not consider data above 8 $\mathrm{km}$ and the statistical error always remains less than $10 \%$. The lower bound of the measurement range is chosen to minimize the effect of the overlap function between the laser beam and the telescope field of view. Regarding the 
systematic error due to atmospheric interferences, only the effect of Rayleigh extinction is corrected using radiosoundings from the nearby WMO station. The systematic error due to the aerosol interference is not corrected in the free troposphere and it is the major term limiting the lidar accuracy [7]. Using error analysis and results from inter-comparison campaigns, the precision of the lidar measurement was estimated to be better than $9 \backslash \%$. The accuracy is of the order of $5 \pm 5$ ppbv.

The seasonal means are calculated for four periods of 5 years: 1991-1995, 1996-2000, 2001-2005 and 2006-2010. At least 40 profiles by period are used to calculate a seasonal average for each instrument. For both instruments, ozone concentrations are first averaged in two layers of $2 \mathrm{~km}$ width in the free troposphere from 4 to $8 \mathrm{~km}$. The top boundary at $8 \mathrm{~km}$ avoids taking into account observations above the tropopause. Because lidar data are less reliable below $3 \mathrm{~km}$ before 2010, the comparison in the range $2-4 \mathrm{~km}$ is not considered.

For each ozone vertical profiles, the transport variability is characterized by three days backward trajectories calculated with FLEXTRA [8] for three altitude levels: $700 \mathrm{hPa}$, $500 \mathrm{hPa}, 400 \mathrm{hPa}$. FEXTRA is initialized with wind fields of ECMWF ERA-interim with a horizontal resolution of $1^{\circ}$ and a vertical resolution of 60 model levels. Three day backward trajectories are also calculated at the same level for every day of the 20-year time series in order to characterize the representativeness of our data sampling.

\section{RESULTS}

The differences between lidar and ECC measurements will be discussed in this section, using seasonal averages and aiming at distinguishing the influence of measurement sampling from differences related to the measurement technique.

According to Figure 1, a maximum in spring/summer and a minimum in winter/fall are seen for both instruments, for the four selected periods. The inter-annual variability of the seasonal means is generally the same for lidar and ECC except in winter/spring at 4-6 km and, in spring and fall at $6-8 \mathrm{~km}$ with lidar showing larger variability. It is a bit surprising that lidar with more observations indicates larger interannual variability. It may only be explained by some inter-annual variability of the meteorological conditions necessary for the lidar observations. Looking at the seasonal differences of ozone ECC minus lidar, the average ozone difference is about $0.9 \mathrm{ppbv}$ in both layers. The error bars on the differences ECC minus lidar correspond to $2 \sigma$ confidence interval. Seasonal differences fluctuate between -5 ppbv and +5 ppbv but they can reach 8 or 12 ppbv in 1996-2000 at both levels and in 20062009 at $6-8 \mathrm{~km}$. The lowest biases are observed for 1991-1995 and 2001-2005 in both layers.

The analysis of the air mass trajectories for both data records show that the largest differences between the geographical air mass origins sampled by lidar and ECC are found in 19961999, in 2001-2005 and in 2006-2009, with ECC being launched more often in air masses coming from the South Western sector. In 19962000 ECC database include also more ascent cases than lidar at $400 \mathrm{hPa}$. Less events with ascending air masses and southerly flow bias low the lidar ozone concentrations in the upper troposphere especially in spring.

Significant transport differences observed in 1996-2000 and 2006-2009 are consistent with the larger ozone seasonal differences $(>10$ ppbv) measured by both instruments. It means that a bias is introduced in the lidar database because of the specific meteorological situations required for the lidar measurement. There is also some kind of bias in the ECC database when using weekly observations. Saunois [9] show that the sampling uncertainty when using 4 profiles per month must be considered as it is often higher than the measurement accuracy. In 2001-2005, differences of air mass origins between both instruments seems to not influence ozone at OHP. In 1991-1995, no bias of transport is observed. Therefore the ozone bias of $0.6 \mathrm{ppbv}$ found in 1991-1995 can be a good proxy for the impact of the instrumental bias on the 5-year seasonal average. 


\section{CONCLUSIONS}

For the first time, ECC and lidar data, available at OHP since 1991, have been compared over a 20 year period. The comparison conducted using this long time series reveals a bias between both measurement types (ECC - lidar) of the order of 0.6 ppbv. This bias is calculated using the seasonal differences for the 5-year period 19911995 (50-80 profiles in average per season) for which the air mass transport differences are lowest. This bias agrees with single profile differences of the order of $81 \%$ observed during ECC/lidar inter-comparison campaigns [3]. Ozone differences larger than $10 \mathrm{ppbv}$ sometimes found between the two datasets can be explained by meteorological biases resulting from a lack of lidar observations for air masses transported from the Low-latitude North Atlantic. In order to have a data base more representative of the various types of air masses observed at OHP, measurements of both instruments have been combined to calculate the seasonal and annual averages.

\section{ACKNOWLEDGEMENT}

The CNRS/INSU, CNES and ADEME are gratefully acknowledged for funding the tropospheric ozone observations at the OHP NDACC station. The engineers operating the lidar and launching ozonesondes at OHP are also acknowledged.

\section{REFERENCES}

[1] Logan, J.A., Staehelin, J., Megretskaia, I.A., Cammas, J.P., Thouret, V., Claude, H., De Backer, H., Steinbacher, M., Scheel, H.E., Stübi, R., Fröhlich, M. Derwent, R., 2012: Changes in ozone over europe: Analysis of ozone measurements from sondes, regular aircraft (MOZAIC) and alpine surface sites. J. Geophys. Res. 117.

[2] Deshler, T., Mercer, J.L., Smit, H.G.J., Stubi, R., Levrat, G., Johnson, B.J., Oltmans, S.J., Kivi, R., Thompson, A.M., Witte, J., Davies, J., Schmidlin, F.J., Brothers, G., Sasaki, T., 2008: Atmospheric comparison of electrochemical cell ozonesondes from different manufacturers, and with different cathode solution strengths: The balloon experiment on standards for ozonesondes, J. Geophys. Research, 113, 10.1029/2007JD008975.

[3] Smit, H., Straeter, W., Johnson, B., Oltmans, S., Davies, J., Tarasick, D., Hoegger, B., Stubi, R., Schmidlin, F., Northam, T., 2007: Assessment of the performance of eccozonesondes under quasi-flight conditions in the environmental simulation chamber: Insights from the Jülich ozone sonde intercomparison experiment (JOSIE). J. Geophys. Res., 112, D19306.

[4] Ancellet, G. Beekmann, M., 1997: Evidence for changes in the ozone concentrations in the free troposphere over southern france from 1976 to 1995. Atmos. Environ., 31, 2835-2851.

[5] Bass A.M. And Paur R.J., 1985: The ultraviolet cross-sections of ozone. i. The measurements. ii - results and temperature dependence, Atmospheric ozone: Proceedings of the Quadrennial Ozone Symposium, Ghazi (Ed.), 606- 616.

[6] Yoshino,K., Freeman, D.E., Esmond, J.R., Parkinson, W.H., 1988: Absolute absorption cross-section measurements of ozone in the wavelength region 238-335 $\mathrm{nm}$ and the temperature dependence, Planetary and Space Science, 36( 4), 395-398.

[7] Ancellet, G., Ravetta, F., 2003: On the usefulness of an airborne lidar for $\mathrm{O} 3$ layer analysis in the free troposphere and the planetary boundary layer, J. Environ. Monit, 5, 47-56 ?

[8] Stohl, A., and Koffi., N.E., 1998: Evaluation of trajectories calculated from ECMWF data against constant volume balloon flights during ETEX. Atmos. Environ., 24, 4151-4156

[9] Saunois, M. and Emmons, L. and Lamarque, J.-F. and Tilmes, S. and Wespes, C. and Thouret, V. and Schultz, M., 2012: Impact of sampling frequency in the analysis of tropospheric ozone observations, Atmos. Chemistry and Physics, 12, 6757-6773. 

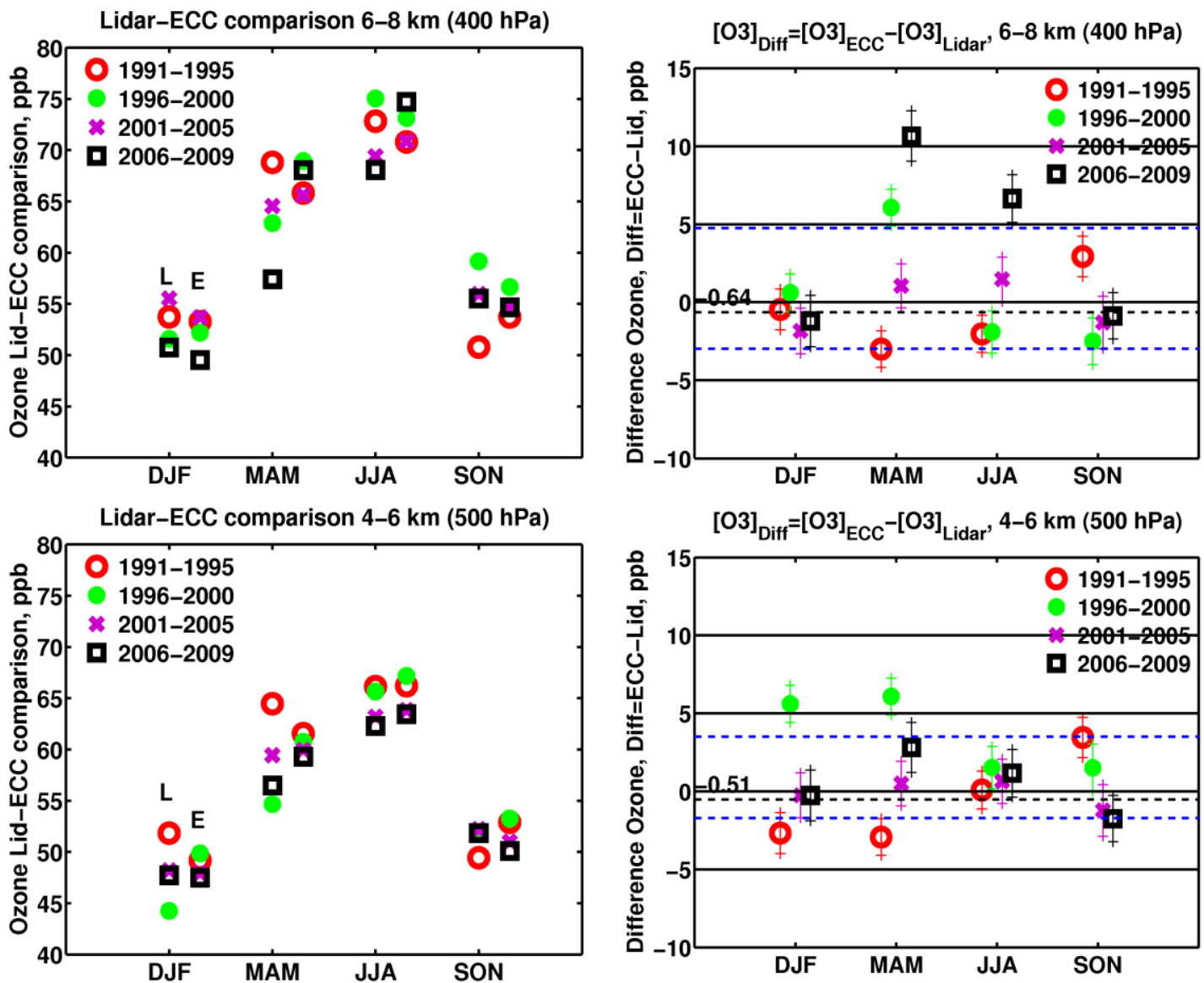

Fig. 1 Seasonal variability of the ozone 5-year average in ppbv for ECC (E) and lidar (L) (left column) and seasonal differences of ozone (ECC minus Lidar) (right column) at 6-8 km (400hPa) (top rank) and 4$6 \mathrm{~km}(500 \mathrm{hPa})$ (bottom rank). Black dotted lines represent the annual average of the seasonal differences of ozone in 1991-1995 taken as the best period to represent instrument differences. Blue dotted lines correspond to the standard deviation $(2 \sigma)$ of all the differences. 